mained intact. He explained this by the assumption that the bacilli have been secreted from the blood by the vessels of the glomeruli, found their way along the tubule in the urinary stream and lodging on its wall set up their specific inflammation. He calls this form of infection "Secretion Tuberculosis." He quotes, in support of his theory, Reisser and Orth, who have demonstrated the same process in pyemic abscess of the kidney, and have shown that bacteria and even foreign bodies, as drops of fat, can be secreted through the glomeruli. Borrell, in this experimental production of renal tuberculosis by the injection of the bacilli into the aorta, has demonstrated their presence in the walls of the vessels of the glomeruli, unaccompanied by inflammatory change. Thus there is a second way in which the bacillus in the blood may produce renal tuberculosis.

Time is not given for the consideration of urogenital tuberculosis though the review of the subject does not seem complete without some mention of this form, and the discussion which its pathogenesis has occasioned.

In this variety the kidney, ureters, prostate and testicle in the male, and the tubes and ovaries in the female, are oftenest affected, much more rarely the bladder. This form of the disease is, as is natural, much more common in the male, and indeed is very rare in females.

Rayer, as early as 1837 , showed that a healthy bladder may be an intermediate between a tubercular testis or prostate, and a similar condition of the kidney. The experiments of Alberran, in which by ligation of one ureter and injection of tubercle bacilli into it above the point of ligation, he proved that the disease may ascend along this tract, is conclusive, but is significant as being the only instance, in many experiments by different observers, which was successful. The ascending form is favored by Rokitansky, Lancereaux, Klebs, Steinthal, Guyon, Duret, and Virchow. Later writers, while acknowledging the possibility of an ascending form, incline to the greater frequency of the descending. So Ziegler, Birsch-Hirschfeld, Senator, Carmargo, Dickinson, Roberts, Casper, Hamill and Israel are more or less positive in the opinion that while tuberculosis may ascend the ureter, it is oftenest primary in the kidney.

The case reported belongs to the chronic variety of renal tuberculosis. The sequence of events is doubtful, and the case might reasonably be regarded as one of the rare instances of renal tuberculosis secondary to cryptogenic infection through the mucous membrane of the intestinal or respiratory tract. However, the adhesions at both apices, and the cavity on the right side, together with the fact that the lesions of the lung is of the type of an infection by inhalation, suggests that, probably the disease was primary in the lung, and that the older lesion was masked by a sudden extension of the process about it, at a comparatively late period, and shortly before death.

The histologic portion of the above report is from the Pepper Laboratory of Clinical Medicine. REFERENCES.

Carmargo: Rev. méd. de la Suisse Romande, 1892

Steinthal: Virchow's Arch., rol.c.
Meyer: Virchow's Arch., vol. cxli.

Dieulafoy: Centralbl, für innere medicin, 1895

Hamill: International Med. Mag., September, 1896.

Krückmann: Virchow's Arch, vol. exxxvii.

The Woes of India.-The $N . Y$. Sun correspondent writing from Jhansi, India, June 22, concludes thus: The close of the sixtieth year of the Queen's reign will be remembered in India for its long death roll, its woes, and its disasters.

\section{IS MALARIA A WATER-BORNE DISEASE?}

Presented to the Section on Practice of Medicine at the Forty-eighth Aunual Meeting of the American Medical Association held at Philadelphig, June 1-4, 1897.

\section{BY JOHN M. BATTEN, M.D.}

PITTSBURG, PA.

Malaria may, to some extent, be a water-borne disease, but that the malaria plasmodium or poison gains admittance into the system wholly by way of the stomach, we think we have ample evidence to lead us to doubt. The plasmodium malariæ or malarial poison certainly gains admittance in to the system through the respiratory organs as well.

I will give a hasty review of the disease as it came under my observation in 1864 and 1865. The Valley City, to which I was attached, had a roving permission to cruise in the sounds of North Carolina and up the rivers that empty into these sounds. The water of the sounds at times is brackish, as it has connection with the ocean through Ocracoke Inlet. The intensity of the disease and the number of cases that occurred increased in the following localities in the order named: 1 , the region of the Pamlico River, upon which Wash. ington. N. C., is situated, is rather free from malaria, though cases occur there; 2, the region of Chowan River, Blackwater River, Meherrin River, and 3, the regions of Roanoke River and Neuse River. Again, on Roanoke Island there is no vegetation, except in the northern part of it, where there are a few scrub oaks. The island is sandy and barren. Yet, one day on that island, with Dr. Walton of the 103d Pennsylvania Regiment I saw a hundred cases of malaria, but many of these cases may have been transferred from other localities. The water used there for drinking and cooking purposes was boiled water taken from the wells on the island.

The water for drinking and cooking purposes on the Valley City was either boiled or distilled, taken from the boiler, cooled and kept in a covered vessel for that purpose. Now, when the Valley City was for a long time up the Roanoke River or other rivers, the cases increased in number and intensity, according to the locality in which she cruised. When cruising up the Roanoke River for a long time the treatment of the disease in many instances would be of no avail, but afterward, when cruising in the sounds or the Atlantic Ocean the disease would respond to treatment, so that there would not be a single case of malaria on board. Afterward, cruising up any of the aforesaid rivers the number of cases and the intensity would increase according to the locality. In the region of the Roanoke River it was intensely malarious, as forest swamps and fogs prevailed there, and many places in this region were impenetrable to man or even the wild beasts of that locality. Why was there a difference in the type of the disease and also the number attacked while in these different localities? It was not the water we drank nor the food we ate, for the water we drank and used for cooking purposes was boiled or distilled. The boiler received its water by pumping from the river, sounds or ocean. Therefore the malarial poison must have been taken into the system through the respiratory organs.

In the fall of 1865, at Cairo, Ill., following a very hot and dry summer, the months of September and October were exceptionally dry and hot. I reported for duty on the United States monitor Oneota, lying off Cairo on the Ohio River, Oct. 6, 1865. Malarial fever was prevalent everywhere in that vicinity. A 
large barge moored to the Oneota was filled with cases of malarial fever of a pernicious type. We used water for drinking and cooking purposes that was boiled or distilled as on the Valley City. What I want to show particularly is, not only that malarial fever prevailed notwithstanding that the water for drinking and cooking purposes was boiled, but that it is not neces. sary to have a wet season follow a dry and warm summer to produce malarial fever or the plasmodium malariæ. Up to Oct. 6,1865 , there had been no rain. The Ohio and Mississippi Rivers were very low, and along the banks of the Ohio in the vicinity of Cairo there was a green scum on the surface of the river, extending some distance from the shore. Yet, as I have said, there was malarial fever prevailing every where in that locality.

Again, in the Western States and in Pennsylvania malarial fever has been actually plowed out of existence. The agriculturist who, for the first time, turned up the soil, suffered the most from malaria, but as the soil was more and more stirred up the less severe and the less frequent would be the attacks, so that today in many localities where the disease was most prevalent, there are no cases of malaria. Was it the water that these early settlers drank, the food they ate, or was it the air they breathed by which the plasmodium malaria or malarial parasites were conveyed into their system?

I hope I have made myself plain on this subject. It is only by observation and experience that we can arrive at a true understanding in regard to this matter. The more plasmodium malariæ that is taken into the system, the oftener the paroxysms of fever will recur, as every day, every second day, etc. Pernicious fever occurs in localities in which the plasmodium malariæ or malarial poison is most intense and most concentrated.

CONVERGENT STRABISMUS.

A CLINICAI LECTURE DELTVERed IN RUSH Medtcal COLlege.

BY ALFRED HINDE, M.D.

CHICAGO, ILL.

I. Its Etrology.

We have read that a child's education ought to be started before its birth; and, in our opinion, the consideration of strabismus is incomplete unless we remember that the ancestral history of these cases often contains an account of one or more persons where the visual line of one eye deviated from the object looked at with the other eye. Such predisposition undoubtedly tends to the production of squint in the offspring. The young of all animals remain with closed eyes for a variable period after birth. The human offspring is no exception. Whether this is due to a sudden change from darkness to light, or because the retinal functional development is inadequate for useful purposes, or because the brain itself is dormant, or because of all these several conditions combined, is unknown. The baby automaton has not yet awoke to the necessities of vision. Its functions are of the lowest forms of life. Its brain, as such, is yet a blank. The first promises of intellectuality are evident when it opens its eyes about the eleventh day (Petersen) and peers around. For some time afterward its vision is general and not special. Its rolls its eyes around regardless of any single object and its attention can not be arrested for a moment by ordinary objects. The center in the brain is then awakening and its anterior prolongation, the optic nerve and retina, is becoming aroused to active life, but as yet the perceptive visual centers of the brain are not alive to the requirements of binocular vision. The eyes roll according to the uncontrolled nerve explosions sent to the external ocular muscles. The complicated government of visual center over motor center is not yet completed, and will not be until the higher center can receive and appreciate the image of an outside object formed on the retina of the observing eye, in short, until the occipital cortex has grown into a sentient perceptive center and asserted its control over the motor centers of the muscles of the eye. The greater the illumination of an object the more quickly it arrests the infant's attention; hence a bright light possesses a first charm to the steady gaze. The retina and entire visual tissue need a strong impulse to whip them into useful activity. By continued practice the function of vision is developed and at last the perceptive visual centers can value at its true worth binocular single vision, and they control the motor centers of the nerves that pass to the eye muscles and so regulate their nerve explosions that the visual line of each eye accurately meets at the object looked at. Briefly, the cerebral function of binocular vision is established "by the end of the second month (Petersen) and we will assume at the same time that the acuity of vision of each eye is alike and perfect. In such a subject there is no likelihood of strabismus and it can only occur from acquired pathologic changes in the ocular tissues. Animals' eyes have a hypermetropic refraction and the nowly born human eye is no exception. It is undersized until puberty ${ }^{1}$ is reached and even then the mujority of human eyes are slightly far-sighted.

The infant's eye being unduly short in its anteroposterior axis the vision of such an eye, in a condition of rest, is imperfect according to the extent of this shortening. In order to focus parallel rays from distant objects accurately upon its retina it must needs exercise its accommodation, because its dioptric system, unaided, has an insufficient refractive power for such rays. Such an eye is adapted only for convergent rays and these are not found in nature. Therefore this hypermetropic eye must either be contented with insufficient focal power, associated with a blurry retinal image and imperfect vision of an outside object, or it elects to use its ciliary muscle to relax its zonula and lens, so that the added refractive power thereby gained is adequate for punctate union of luminous rays entering its pupil. Within a limited runge this function of accommodation can be exercised alone or without any associuted convergence, and it is by such means that youthful far-sighted eyes can add to their established binocular vision the power of seeing distant objects clearly. With binocular fixution, therefore, and normal acuity of vision such eyes are free from the probability of strabismus. The infant considers only distant objects and in predisposed cases strabismus does not occur until the child's curiosity has called forth the desire to observe near objects. This intellectual aocomplishment is not reached earlier than the second year of life and it is during this period ${ }^{2}$ that our squint cases begin to develop. 'They increase numerically up to the sixth year and are of the convergent variety.

1 Twelve to eighteen years of age. Landolt, "Accommodation and Refraction of the liye," p. 444.

2 Aceording to Petersen (Amer. Journal of Insanity, July, 1896), a normal child begins to distinguish colors correctly about the age of two years. 